\title{
NOTA PRÉ-EDITORIAL
}

\author{
Marcus Novaes \\ Alik Wunder \\ Rosana Baptistella
}

"La multiplicidad de las perspectivas sobre la cosa define precisamente a la cosa, que nunca es

únicamente lo que es."

(DELEUZE, 2019, p. 197)

A Revista Linha Mestra 38 traz um dossiê com artigos de autores que estiveram presentes no Primer Congreso Internacional Devenir Animal - La Filosofía de Gilles Deleuze y Félix Guattari, realizado entre os dias 20 e 22 de março de 2019, na cidade de Quito-Ecuador e organizado, conjuntamente, pela Facultad De Ciencias Sociales Y Humanas de la universidad Central del Ecuador e pela Red de Estudios Latinoamericanos Deleuze y Guattari (REELD\&G).

Trata-se de um número especial e que traz textos, em português e espanhol, que nos convidam a pensar a filosofia de Gilles Deleuze e Felix Guattari com as Artes, Estudos Fílmicos, Educação, Política, a própria Filosofia, entre outros campos do pensamento, desde uma perspectiva latinoamericana.

Por ser uma edição bilíngue, convidamos a compartir essa edição um dos organizadores do Congresso, o professor Eduardo Alberto León, que apresenta o dossiê, e o professor Patricio Landaeta Mardones, responsável pela REELD\&G e que apresenta o editorial.

Desejamos uma alegre e provocativa leitura! 